\title{
Tissue-Engineered Mandibular Bone Reconstruction for Continuity Defects: A Systematic Approach to the Literature
}

\author{
Nattharee Chanchareonsook, DDS, MDS, ${ }^{1, *}$ Rüdiger Junker, DDS, $\mathrm{PhD}^{2,3, *}$ \\ Leenaporn Jongpaiboonkit, $\mathrm{PhD},{ }^{4}$ and John A. Jansen, DDS, $\mathrm{PhD}^{3}$
}

Background: Despite significant surgical advances over the last decades, segmental mandibular bone repair remains a challenge. In light of this, tissue engineering might offer a next step in the evolution of mandibular reconstruction.

Purpose: The purpose of the present report was to (1) systematically review preclinical in vivo as well as clinical literature regarding bone tissue engineering for mandibular continuity defects, and (2) to analyze their effectiveness. Materials and Methods: An electronic search in the databases of the National Library of Medicine and ISI Web of Knowledge was carried out. Only publications in English were considered, and the search was broadened to animals and humans. Furthermore, the reference lists of related review articles and publications selected for inclusion in this review were systematically screened. Results of histology data and amount of bone bridging were chosen as primary outcome variables. However, for human reports, clinical radiographic evidence was accepted for defined primary outcome variable. The biomechanical properties, scaffold degradation, and clinical wound healing were selected as co-outcome variables.

Results: The electronic search in the databases of the National Library of Medicine and ISI Web of Knowledge resulted in the identification of 6727 and 5017 titles, respectively. Thereafter, title assessment and hand search resulted in 128 abstracts, 101 full-text articles, and 29 scientific papers reporting on animal experiments as well as 11 papers presenting human data on the subject of tissue-engineered reconstruction of mandibular continuity defects that could be included in the present review.

Conclusions: It was concluded that (1) published preclinical in vivo as well as clinical data are limited, and (2) tissueengineered approaches demonstrate some clinical potential as an alternative to autogenous bone grafting.

\section{Introduction}

$\mathbf{M}$ ANDIBULAR CONTINUITY DEFECTS result from a variety of causes, including maxillofacial trauma, osteomyelitis, osteonecrosis, and resection of benign or malignant tumors. ${ }^{1,2}$ Unrepaired defects are associated with defacement, reduced masticatory capability, and loss of speech, which severely affect the patient's quality of life. Ideally, mandibular continuity defect reconstruction should not only restore the anatomical height and contour of the missing part, but should, in addition, allow re-establishment of oral function. ${ }^{1}$ Until now, autogenous bone transplantation-especially free vascularized tissue transfer-is considered a "gold standard of care" for mandibular reconstruction in patients undergoing major ablative surgery. ${ }^{2-4}$ In principle, autogenous bone grafts provide all critical factors for bone regeneration, such as a scaffold for osteo-conduction, growth factors for osteoinduction, and cells for osteogenesis. ${ }^{5}$ However, the major problem of this approach is the requirement of autogenous donor tissue, which results, for example, in donor-site morbidity. ${ }^{6}$ Moreover, despite the availability of various reconstructive methods by means of autogenous tissue, perfect mandibular reconstruction, including restoration of continuity, sensation, dentition, soft tissue, function, and aesthetics, is still not achievable. ${ }^{1,2}$ As a consequence, mandibular bone reconstruction still remains a challenge. ${ }^{2}$

However, development of reliable tissue engineering techniques might offer a next step in the evolution of mandibular reconstruction. ${ }^{2,7}$ By definition, tissue engineering was defined as an interdisciplinary field that applies the

\footnotetext{
${ }^{1}$ Department of Oral and Maxillofacial Surgery, National Dental Centre Singapore, Singapore, Singapore.

Departments of ${ }^{2}$ Implantology and Periodontology and ${ }^{3}$ Biomaterials, Radboud University Nijmegen Medical Center, Nijmegen, The Netherlands.

${ }^{4}$ Tissue Regeneration Systems, Inc., Ann Arbor, Michigan.

*These authors contributed equally to this work.
} 
principles of engineering and the life sciences toward the development of biological substitutes which restore, maintain, or improve tissue function. ${ }^{8}$ Bone tissue engineering is a relatively new method that uses scaffolds, bioactive substances, and/or cells/tissues with osteogenic potential. ${ }^{1}$ Ideally, the scaffolds should be (1) three dimensional and highly porous with an interconnected pore network for cell growth and flow transport of nutrients and metabolic waste as well as (2) biocompatible and bioresorbable with a controllable degradation and resorption rate to match cell or tissue growth. Furthermore, these scaffolds should possess (3) suitable surface chemistry for cell attachment, proliferation, and differentiation, and (4) mechanical properties to match those of the tissues at the site of implantation. ${ }^{9}$ At present, a multitude of scaffolds made of various material $^{10-19}$ in combination with bioactive substances or osteogenic bone marrow stromal cells (BMSCs) ${ }^{10,20-26}$ to initiate or enhance bone formation ${ }^{15-17,19,27-33}$ are under study.

In 2006, Ikada defined a concept on methodology in tissue engineering as (1) placing the construct scaffold in a bioreactor to reconstruct an engineered tissue in vitro called in vitro (or ex vivo) tissue engineering and (2) implantation of the construct scaffold in the body until a new tissue is regenerated in vivo called in vivo (or in situ) tissue engineering. ${ }^{34}$ However, the construct completely lacks a pre-existing vasculature. Cell survival and tissue formation will depend on local vasculature and the speed at which a fully functional vascular supply will be developed. ${ }^{35}$ This makes that the reconstruction of large-volume defects, such as mandibular continuity defects, remains challenging. Therefore, vascularization concepts gain interest and the combination of tissue engineering approaches with flap prefabrication techniques. This may eventually allow application of bonetissue substitutes grown in vivo with the advantage of minimal donor site morbidity as compared with conventional vascularized bone grafts. ${ }^{12}$ This review included the concepts of tissue engineering using axial vascularization in engineered bone tissues.

Nonetheless, to the best of the authors' knowledge, animal experiments as well as clinical case reports or studies on the subject of bone tissue engineering for mandibular continuity defects are currently neither systematically reviewed nor synopsized.

Therefore, the purpose of the present report was (1) to review systematically preclinical in vivo and clinical literature regarding bone tissue engineering for mandibular continuity defects, and (2) to analyze their effectiveness.

\section{Materials and Methods}

\section{Study design}

The scientific, preclinical in vivo and clinical literature regarding tissue engineered approaches for mandibular bone regeneration in continuity defects (i.e., segmental mandibular defects or total mandibular condyle replacements) was systematically reviewed.

\section{Outcome variables}

In principle, for animal experiments as well as human reports, macroscopical or histological or histomorphometric data on the amount of total bone defect bridging were cho- sen as a primary outcome variable. However, for human reports, clinical and/or radiographic evidence of the restoration of mandibular continuity was accepted as a surrogate outcome variable for the presently defined primary outcome variable. Concomitantly, histological or histomorphometric data of bone ingrowth, results of biomechanical testing, histological or histomorphometric records of scaffold degradation as well as clinical wound healing were selected as co-outcome variables.

\section{Inclusion/exclusion criteria}

In general, only animal in vivo experiments and human reports presenting macroscopical or histological or histomorphometric data on the amount of total bone defect bridging, histological or histomorphometric data of bone ingrowth, results of biomechanical testing, histological or histomorphometric data of scaffold degradation or information related to clinical wound healing, as well as human reports presenting clinical and/or radiographic evidence of restoration of mandibular continuity were included.

The following detailed inclusion criteria were used:

1. Research paper presenting in vivo animal data;

2. Research paper presenting human data;

3. Defect characteristics should be clearly stated;

4. Implantation site should be clearly mentioned;

5. Reconstructive technique (i.e.: tissue engineering) should be clearly stated;

6. Healing period should be clearly stated;

7. The animal model used should be described conspicuously (species, age);

8. Amount of total bone defect bridging, and/or percentage of bone ingrowths, and/or results of biomechanical testing, and/or percentage scaffold degradation, and/ or information related to clinical wound healing had to be presented;

9. For human reports, clinical and/or radiographic evidence of restoration of mandibular continuity had to be presented

Studies that did not meet all the inclusion criteria mentioned earlier, for example, ex-vivo studies or studies not addressing tissue-engineered approaches for mandibular bone regeneration in continuity defects, were excluded.

\section{Search strategy}

An electronic search in the database of the National Library of Medicine (www.ncbi.nlm.nih.gov) up to September 30, 2012 was carried out. Only publications in English were considered, and the search was broadened to animals and humans. The following search strategy was applied: (("tissue engineering"[MeSH Terms] OR ("tissue"[All Fields] AND "engineering"[All Fields]) OR "tissue engineering"[All Fields]) OR ("tissue scaffolds"[MeSH Terms] OR ("tissue"[All Fields] AND "scaffolds"[All Fields]) OR "tissue scaffolds"[All Fields] OR ("tissue"[All Fields] AND "scaffold"[All Fields]) OR "tissue scaffold"[All Fields]) OR ("reconstructive surgical procedures"[MeSH Terms] OR ("reconstructive"[All Fields] AND "surgical"[All Fields] AND "procedures"[All Fields]) OR "reconstructive surgical procedures"[All Fields] OR "reconstruction"[All Fields]) OR ("bone morphogenetic proteins"[MeSH Terms] OR 
("bone"[All Fields] AND "morphogenetic"[All Fields] AND "proteins"[All Fields]) OR "bone morphogenetic proteins"[All Fields] OR ("bone"[All Fields] AND "morphogenetic"[All Fields] AND "protein"[All Fields]) OR "bone morphogenetic protein"[All Fields]) OR ("bone marrow cells"[MeSH Terms] OR ("bone"[All Fields] AND "marrow"[All Fields] AND "cells"[All Fields]) OR "bone marrow cells"[All Fields]) OR ("intercellular signaling peptides and proteins"[MeSH Terms] OR ("intercellular"[All Fields] AND "signaling"[All Fields] AND "peptides"[All Fields] AND "proteins"[All Fields]) OR "intercellular signaling peptides and proteins"[All Fields] OR ("growth"[All Fields] AND "factors"[All Fields]) OR "growth factors"[All Fields])) AND (("mandible"[MeSH Terms] OR "mandible"[All Fields]) OR (("mandible"[MeSH Terms] OR "mandible"[All Fields] OR "mandibular"[All Fields]) AND ("Continuity"[Journal] OR "continuity"[All Fields]) AND defect [All Fields])).

In addition, the ISI Web of Knowledge database was searched operating the same MeSH terms. Again, only publications in English reporting on animal experiments and human studies were considered.

Furthermore, the reference lists of related review articles and publications selected for inclusion in this review were systematically screened.

\section{Study selection}

Two independent reviewers (N.C. and L.J.) initially screened the publication titles and abstracts as identified by the electronic as well as manual search for possible inclusion. Full texts of all papers that were considered eligible for inclusion by one or both of the reviewers were obtained for further assessment against the stated inclusion criteria (Fig. 1). Both reviewers used an identical data extraction form to acquire the data independently. Any disagreement between the reviewers regarding inclusion of a certain publication or data extraction was resolved by discussion.

\section{Results}

\section{Study selection}

The electronic search in the databases of the National Library of Medicine and ISI Web of Knowledge resulted in the identification of 6727 and 5017 titles, respectively.

As already mentioned, these titles were initially screened by two independent reviewers (N.C. and L.J.) for possible inclusion. In order not to exclude scientific reports unintended, title screening as well as abstract assessment was accomplished to identify articles reporting, in general, on mandibular defect reconstruction (i.e., noncontinuity as well as continuity defects). Title assessment and hand search resulted in the final selection of 128 abstracts, 101 full-text articles, and 40 scientific papers reporting on tissue-engineered reconstruction of mandibular continuity defects that could be included in the present review (Fig. 1, Tables 1-4). Regarding data extraction and interpretation, any disagreement between the reviewers was resolved by discussion.

\section{General characteristics of the included studies}

In total, 29 papers reported on animal experiments. Twentyseven of these articles presented data on segmental mandibular body reconstruction, $4,10,11,15-19,25,26,29-33,97-103,105-107,109,110$ one article reported on mandibular angle reconstruction, ${ }^{104}$ and another one presented data on mandibular condyle reconstruction. ${ }^{108}$ Research was done in rabbits, ${ }^{30,108}$ sheep, ${ }^{11,16,17,19,100,107}$ goats, ${ }^{104,105}$ as well as in minipigs, ${ }^{33}$ $\operatorname{dogs}^{4,10,25,26,31,32,97,98,106,110}$, and monkeys. ${ }^{15,18,29,99,101-103,109}$ In several studies, teeth were extracted in advance, and oral mucosa was allowed to heal completely before resective surgery and reconstructive therapy. ${ }^{4,26,105,106}$ Beside the diversity in animal models, study design as well as healing periods after reconstructive surgery (range: 4-48 weeks) were not uniform. The follow-up periods were related to differences in animal species; for example, dog (12-48 weeks), monkey (16-30 weeks), sheep (12-20 weeks), rabbit (12-16 weeks), goat (6-16 weeks), and minipigs (16 weeks).

Furthermore, 11 out of the 40 articles presented human data on mandibular reconstruction. ${ }^{111-121}$

The general characteristics of the included animal and clinical studies are summarized in Tables 3 and 4 .

\section{Animal studies}

Autogenous bone precursor cells or autogenous osteogenic tissues. As described, bone tissue engineering is an approach that combines scaffolds with osteogenic cells/ tissues and/or bioactive substances. In preclinical animal models, in principle, two different strategies for bone reconstruction in continuity defects have been intensively investigated, that is, the implantation of autogenous bone precursor cells or autogenous osteogenic tissues-which contain osteoprogenitor cells and/or mesenchymal stem cells-and the application of bone morphogenetic proteins. Both were combined with a range of different carrier biomaterials.

In total, 12 scientific papers ${ }^{4,10,11,18,25,26,100,104-108}$ reporting on autogenous bone precursor cells or autogenous osteogenic tissues were finally appropriate for inclusion in the current systematic review. Due to their experimental diversity, these studies are briefly summarized (Details can be found in Addendum No. 1 in Supplementary Data; Supplementary Data are available online at www.liebertpub.com/ teb).

In summary, autogenous bone precursor cells or autogenous osteogenic tissues were primarily combined with calcium phosphate ceramic scaffolds, such as beta-tri calcium phosphate $(\beta-\mathrm{TCP})^{4,11,25,26,106}$ and biphasic calcium phosphate ceramic, ${ }^{26}$ or pyrolized bovine bone ${ }^{100}$ or calcium carbonate, such as natural corals. ${ }^{10,105}$ Considering the primary outcome variable bone bridging $4,11,18,26,104-107,117$ as well as the co-outcome variables bone ingrowth $\mathrm{h}^{100}$ and biomechanical testing, ${ }^{4,10,25}$ autogenous bone precursor cells or autogenous tissues seeded onto calcium phosphate ceramic scaffolds showed in preclinical animal studies the potential of an alternative to autograft bone for mandibular bone reconstruction in continuity defects. Moreover, autogenous bone precursor cells or autogenous osteogenic tissues seeded onto or mixed with collagen sponges ${ }^{18,108}$ demonstrated in preclinical animal studies promising results in terms of the primary outcome variable bone bridging ${ }^{18}$ or the co-outcome variable bone ingrowths. ${ }^{108}$ In contrast, autogenous bone precursor cells containing tissues filled in preshaped poly-D, L-lactide trays did not show such a potential as an alternative to autograft bone for mandibular bone reconstruction. ${ }^{104}$ 


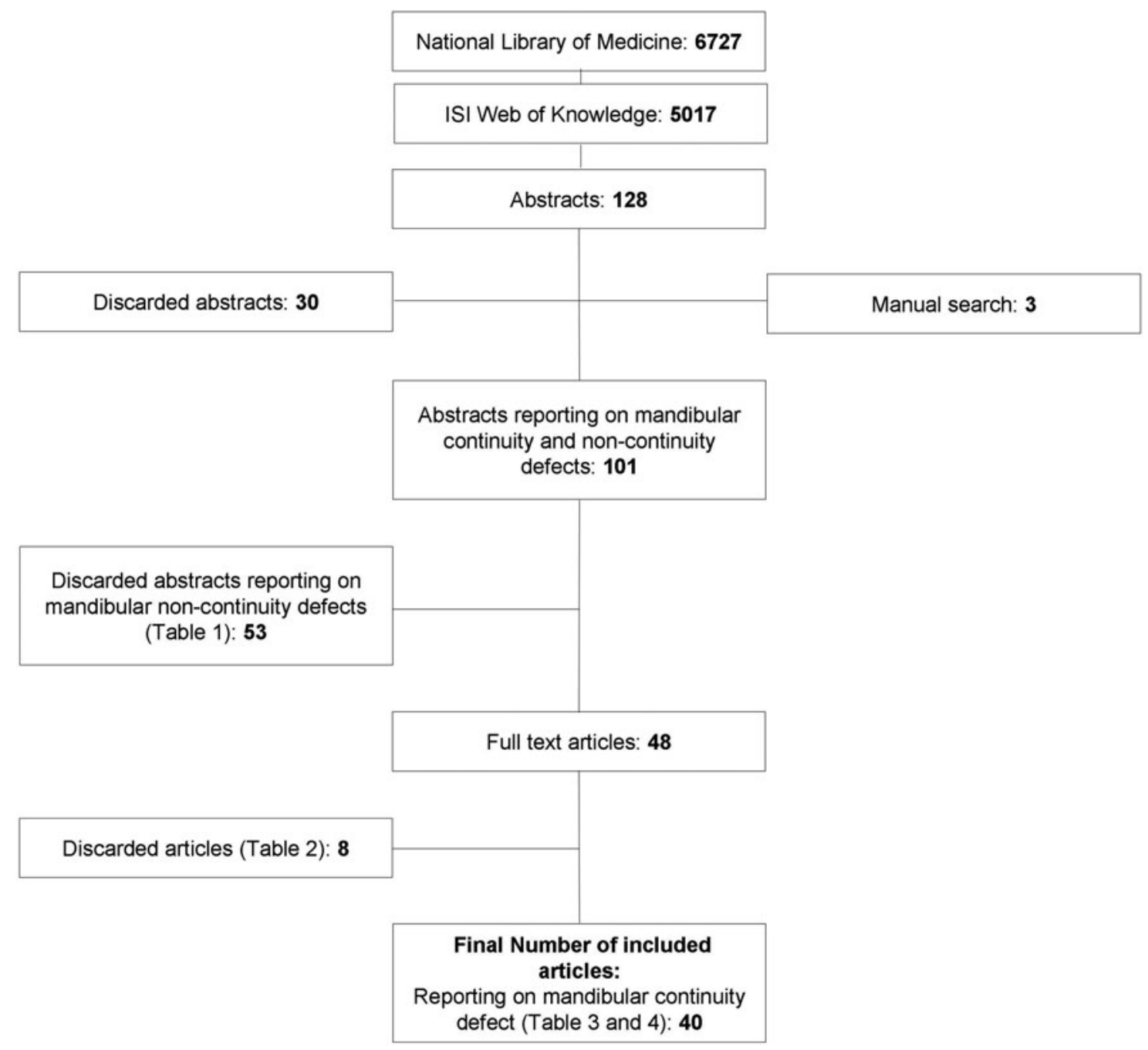

FIG. 1. Selection process.

\section{Bone morphogenetic proteins}

Furthermore, in total, 15 scientific papers ${ }^{15,18,29,31,32,97-}$ $99,101-103,105,106,109,110$ reporting on recombinant human bone morphogenetic protein-2 (rhBMP-2) as well as five publications ${ }^{16,17,19,30,33}$ presenting data on recombinant human bone morphogenetic protein-7 (rhBMP-7) were eventually included in the current systematic approach. Thereby, the brief summarized studies of Kontaxis et al., ${ }^{16}$ Abu-Serriah et al., ${ }^{19}$ Boyne, ${ }^{29,101}$ Busuttil Naudi et al., ${ }^{30}$ and Toriumi et al. ${ }^{97}$ may give a good general impression of the effectiveness of rhBMPs regarding the quantity as well as quality of induced bone for the reconstruction of continuity mandibular defects (Details can be found in Addendum No. 2 in Supplementary Data).

In summary, rhBMP-2 and rhBMP-7 were studied in combination with collagen/collagen composite scaffolds, ${ }^{15-19,29,32,33,99,101,108,110}$ poly-D,L-lactide coglycolic acid based carriers. ${ }^{31,98,102,103} \beta-\mathrm{TCP}^{30}$, as well as coralline hydroxyapatite ${ }^{109}$ and allogenic bone matrix. ${ }^{97}$ Regarding the primary outcome variable bone bridging ${ }^{15-19,29-33,97-}$ $99,101-103,109,110$ as well as the co-outcome variables bone ingrowths ${ }^{17-19,29,30,32,33,97-99,109}$ and biomechanical testing, ${ }^{16,19,30,33,97}$ rhBMP-2 and rhBMP-7 demonstrated in preclinical animal studies their potential as an alternative to autograft bone for mandibular bone reconstruction in continuity defects. However, the published results were not uniform. It should be mentioned that in different reports, rhBMP-2 or rhBMP-7 combined with demineralized freeze-dried bone allograft, ${ }^{109}$ polyglycolic co-lactic acid, ${ }^{102}$ and a bovine collagen type I carrier wrapped into a sterno-occipitalis muscle flap ${ }^{17}$ were not associated with predictable defect bridging.

In line with these results are the reported effects of rhBMP$2^{15,31,32,98,99,103,110}$ and rhBMP- $7^{33}$ for mandibular bone regeneration in continuity defects. On the other hand, it should be mentioned that rhBMP-2, in the reports of Zhou et al. ${ }^{109}$ and Seto et al., ${ }^{102}$ as well as rhBMP-7, in the paper of Ayoub et al., ${ }^{17}$ have not always been associated with bony union. Likewise, in the paper of Ayoub et al., ${ }^{17}$ rhBMP-7 was not in all animals associated with complete bone regeneration.

\section{Human case report}

In addition to animal experiments, bone tissue engineering for reconstruction of mandibular continuity defects has been investigated in humans. Similar to preclinical models, 
Table 1. Excluded Articles: Reporting on Noncontinuity Defects

\begin{tabular}{|c|c|c|c|}
\hline No & Year & Authors & Journal \\
\hline 1. & 1998 & Schliephake et al. ${ }^{36}$ & J Oral Maxillofac Surg 56, 616, 1998. \\
\hline 2. & 2002 & Fisher et al. $^{37}$ & $\begin{array}{l}\text { Engineering in Medicine and Biology, 2002. 24th Annual Conference and } \\
\text { the Annual Fall Meeting of the Biomedical Engineering Society EMBS/BMES } \\
\text { Conference, 2002. Proceedings of the Second Joint } 2002 \text { Oct 1, pp. 827-828. }\end{array}$ \\
\hline 3. & 2002 & Chu et al. ${ }^{38}$ & Biomaterials 23, 1283, 2002. \\
\hline 4. & 2003 & Gröger et al. ${ }^{39}$ & Scand J Plast Reconstr Surg Hand Surg 37, 129, 2003. \\
\hline 5. & 2003 & Nakahara et al. ${ }^{40}$ & Tissue Eng 9, 153, 2003. \\
\hline 6. & 2004 & Abukawa et al. ${ }^{41}$ & J Oral Maxillofac Surg 62, 601, 2004. \\
\hline 7. & 2004 & Yamada et al. ${ }^{42}$ & Cell Transplant 13, 343, 2004. \\
\hline 8. & 2004 & Yamada et al. $^{43}$ & Clin Oral Implants Res 15, 589, 2004. \\
\hline 9. & 2005 & Ito et al. & J Biomed Mater Res Part A 73, 63, 2005. \\
\hline 10. & 2005 & Li et al. ${ }^{45}$ & Aust N Z J Surg 75, 1017, 2005. \\
\hline 11. & 2005 & Marei et al. ${ }^{46}$ & Tissue Eng 11, 751, 2005. \\
\hline 12. & 2005 & Meyer et al. ${ }^{47}$ & Int J Oral Maxillofac Implants 20, 882, 2005. \\
\hline 13. & 2005 & Ren et al. ${ }^{48}$ & J Biomed Mater Res Part A 74, 562, 2005. \\
\hline 14. & 2006 & Ito et al. ${ }^{49}$ & Clin Oral Implants Res 17, 579, 2006. \\
\hline 15. & 2007 & Mylonas et al..$^{50}$ & J Prosthodont 16, 421, 2007. \\
\hline 16. & 2007 & Ren et al. 51 & J Biomater Sci Polym Ed 18, 505, 2007. \\
\hline 17. & 2007 & Rai et al..$^{52}$ & J Oral Maxillofac Surg 65, 2195, 2007. \\
\hline 18. & 2007 & Wang et al. ${ }^{53}$ & Biomaterials 28, 3338, 2007. \\
\hline 19. & 2007 & Zhang et al. ${ }^{54}$ & Biomaterials 28, 4635, 2007 \\
\hline 20. & 2008 & Kuznetsov et al. ${ }^{55}$ & Biomaterials 29, 4211,2008 \\
\hline 21. & 2008 & Tang et al. 56 & Cell Biol Int 32, 1150, 2008. \\
\hline 22. & 2008 & Wang et al. ${ }^{57}$ & J Clin Rehab Tissue Eng Res 12, 9762,2008. \\
\hline 23. & 2009 & Abukawa et al. ${ }^{58}$ & J Oral Maxillofac Surg 67, 335, 2009. \\
\hline 24. & 2009 & Appleford et al. ${ }^{59}$ & J Biomed Mater Res Part A 89, 1019, 2009. \\
\hline 25. & 2009 & $\mathrm{~d}^{\prime}$ Aquino et al. ${ }^{60}$ & Eur Cells Mater 18, 75, 2009 \\
\hline 26. & 2009 & Guo et al. ${ }^{61}$ & Acta Biomater 5, 268, 2009. \\
\hline 27. & 2009 & Jiang et al. ${ }^{62}$ & Biomaterials 30, 4522, 2009. \\
\hline 28. & 2009 & Schliephake et al. ${ }^{63}$ & Int J Oral Maxillofac Surg 38, 166, 2009. \\
\hline 29. & 2009 & Schuckert et al. ${ }^{64}$ & Tissue Eng Part A 15, 493, 2009. \\
\hline 30. & 2009 & Shi et al. ${ }^{65}$ & J Biomater Appl 23, 331, 2009. \\
\hline 31. & 2009 & Wang et al. ${ }^{66}$ & Biomaterials 30, 2489, 2009. \\
\hline 32. & 2009 & Yao et al. ${ }^{67}$ & J Biomed Mater Res Part B Appl Biomater 91, 805, 2009. \\
\hline 33. & 2009 & Yoshimi et al. ${ }^{68}$ & J Craniofac Surg 20, 1523, 2009. \\
\hline 34. & 2009 & Zhang et al. ${ }^{69}$ & Biomed Mater 4, 045007, 2009. \\
\hline 35. & 2009 & Zhang et al. ${ }^{70}$ & J Controlled Release 136, 172, 2009. \\
\hline 36. & 2009 & Zhao et al. ${ }^{71}$ & Bone 45, 517, 2009. \\
\hline 37. & 2009 & Zheng et al. ${ }^{72}$ & J Dent Res 88, 249, 2009. \\
\hline 38. & 2010 & Gallego et al. ${ }^{73}$ & Tissue Eng Part A 16, 1179, 2010. \\
\hline 39. & 2010 & Huang et al. ${ }^{74}$ & J Biomed Mater Res Part A 95, 993, 2010. \\
\hline 40. & 2010 & $\mathrm{Li}$ et al. & J Biomed Mater Res Part A 95, 973, 2010. \\
\hline 41. & 2010 & Parrilla et al. ${ }^{76}$ & Arch Otolaryngol Head Neck Surg 137, 463, 2011. \\
\hline 42. & 2010 & Ribeiro et al. ${ }^{77}$ & J Clin Periodontol 37, 1128, 2010. \\
\hline 43. & 2010 & Zhao et al. ${ }^{78}$ & Oral Diseases 16, 46, 2010. \\
\hline 44. & 2011 & Dormer et al. ${ }^{79}$ & J Oral Maxillofac Surg 69, e50, 2011. \\
\hline 45. & 2011 & Kohgo et al. ${ }^{80}$ & Int J Periodontics Restorative Dent 31, e9, 2011. \\
\hline 46. & 2011 & Ito et al. ${ }^{81}$ & Int J Oral Maxillofac Implants 26, 947, 2011. \\
\hline 47. & 2011 & Parrilla et al. ${ }^{82}$ & Head Neck 32, 310, 2010. \\
\hline 48. & 2011 & Yamada et al. ${ }^{83}$ & Cell Transplant 20, 1003, 2011. \\
\hline 49. & 2011 & Zhu et al. ${ }^{84}$ & Osteoarthritis Cartilage 19, 743, 2011. \\
\hline 50. & 2012 & Yeo et al. ${ }^{85}$ & Clin Oral Implants Res 23, 1322, 2012. \\
\hline 51. & 2012 & Vahabi et al. ${ }^{86}$ & Chang Gung Med J 35, 28, 2012. \\
\hline 52. & 2012 & Zhou et al. ${ }^{87}$ & Mater Sci Eng C 32, 994, 2012. \\
\hline 53. & 2012 & Zou et al. ${ }^{88}$ & PLoS One 7, e32355, 2012. \\
\hline
\end{tabular}

considerable interest for therapeutic use has been focused on the application of autogenous osteogenic tissues or bone morphogenetic proteins, both of which are combined with a range of different carrier biomaterials. In total, 11 scientific papers ${ }^{111-121}$ reporting on 10 different investigation entities were finally included in the current systematic review.

\section{Autogenous osteogenic tissues and bone morphogenetic proteins (Details can be found in Addendum No. 3 in Supplementary Data)}

In summary, transplantation of tissue-engineered autogenous osteogenic tissues without additional application of 


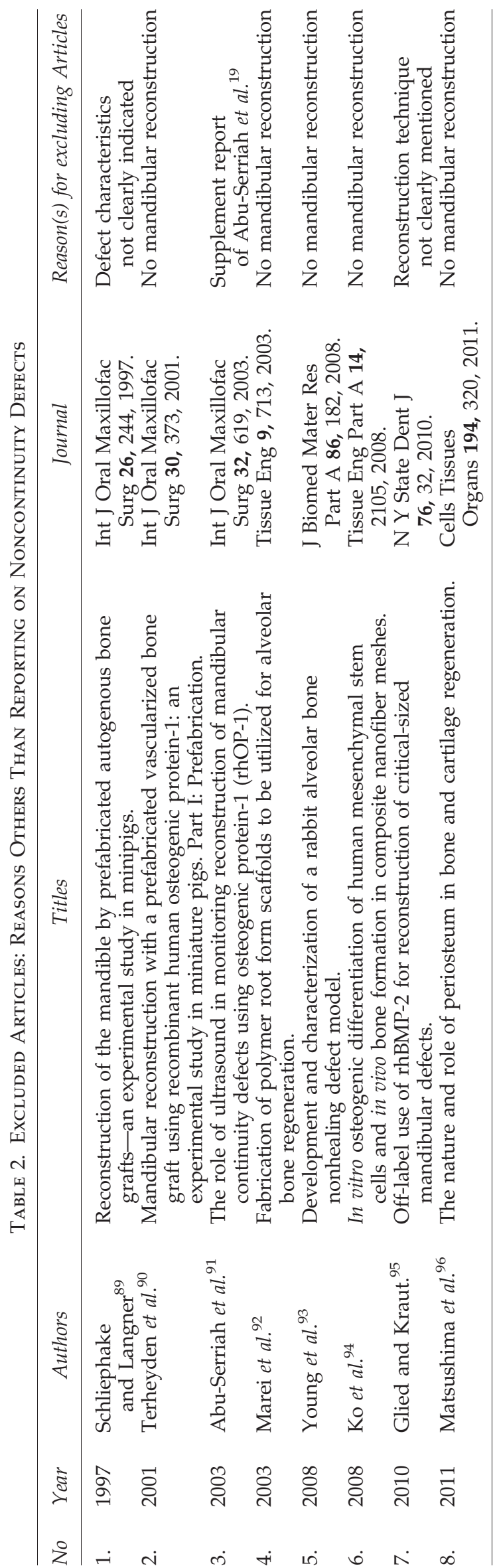

osteoinductive $\mathrm{BMPs}^{119}$ or in combination with rhBMP$2^{115,117,120}$ as well as rhBMP-7 $7^{110,111}$ was associated with restored mandibular continuity in five cases, but in one case, ${ }^{117}$ no bony union was observed. Furthermore, in 16 patients in some reports, ${ }^{115,118,121}$ osteoinductive rhBMP-2 loaded onto different biomaterials without concomitant transplantation of autogenous osteogenic tissue was followed by restored mandibular continuity. Again, this did not occur in one subject. ${ }^{117}$ Moreover, in 10 patients rhBMP-7, ${ }^{116}$ in one patient native human BMPs ${ }^{111}$ and in two patients xenogeneic BMPs $^{112}$ without concurrent transplantation of autogenous osteogenic tissue were associated with reconstructed mandibular continuity. However, this was not observed in four subjects treated with xenogeneic BMPs. ${ }^{112}$

\section{Discussion}

Currently, bone tissue engineering can be considered a highly promising approach and as an alternative bone source. Well-performed in vitro and in vivo experiments are essential to determine the suitability of the chosen concept and to understand the risks before proceeding into the clinical trial. ${ }^{122,123}$ In vitro studies require a desired monitored environment that mimics the dynamics of the in vivo condition by a controlled homogeneity of nutrients media (also in terms of $\mathrm{pH} /$ osmolarity), additional osteogenic stimuli(s), and providing a physical stimulation as relevant key components for bone construction. ${ }^{124}$ However, the in vitro condition is unable to provide physiological function and is never exactly the same condition as the in vivo one. ${ }^{124}$ The results from in vitro studies do not give direct information or can be difficult to infer from the in vivo situation, ${ }^{125}$ but are rather considered baseline properties. ${ }^{126}$ For this reason, the use of animal models is often an essential step in the testing of tissue engineering before clinical use.

The aims of the present report were to review systematically preclinical in vivo as well as clinical literature regarding bone tissue engineering for mandibular continuity defects and to analyze the effectiveness of this approach for the treatment of mandibular continuity defects.

In total, 29 publications reporting on animal experiments and 11 papers presenting human cases could be included in the present systematic review. The evaluated articles of the first part of the current review report on tissue-engineered reconstructions of segmental mandibular body, angle, or condyle defects in different animal species. Thus, autogenous bone precursor cells or autogenous osteogenic tissues were primarily combined with calcium phosphate ceramic scaffolds. Regarding bone bridging, bone ingrowth, as well as biomechanical testing, these tissue-engineered approaches demonstrated a certain potential as an alternative to autograft bone for mandibular bone reconstruction in continuity defects. In principle, these results were not unexpected and were in line with the literature for bone tissue engineering in general. It is well known that BMSCs are capable of selfrenewal and differentiation into various osteogenic lineage cells. ${ }^{127}$ Furthermore, their osteogenic potential has been demonstrated both in vitro and in vivo. Consequently, BMSCs became a major seed cell source for bone tissue engineering. Moreover, many previous studies have succeeded in repairing bone defects by using BMSCs in animal models as well as in humans. ${ }^{24,127-129}$ 


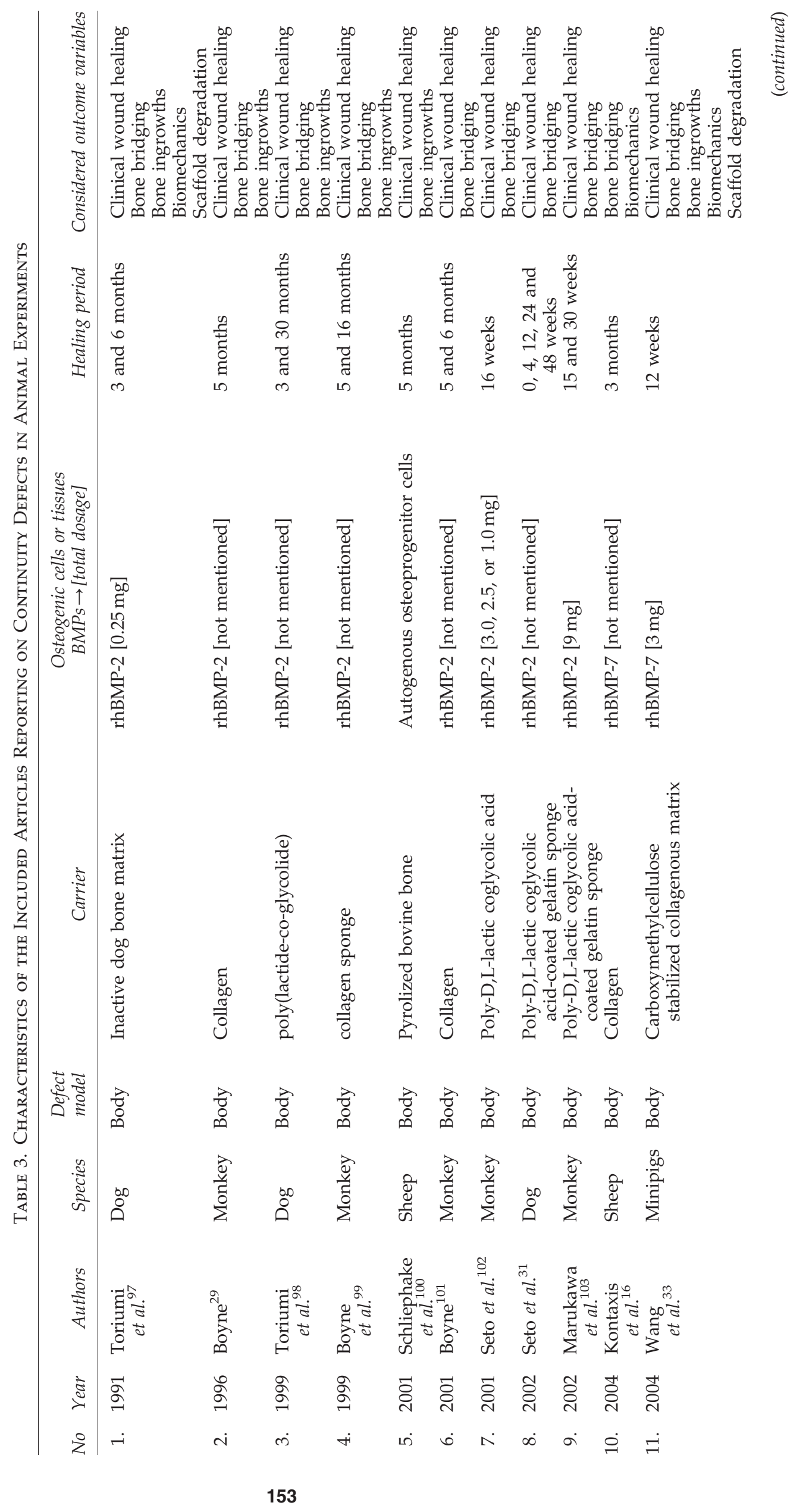




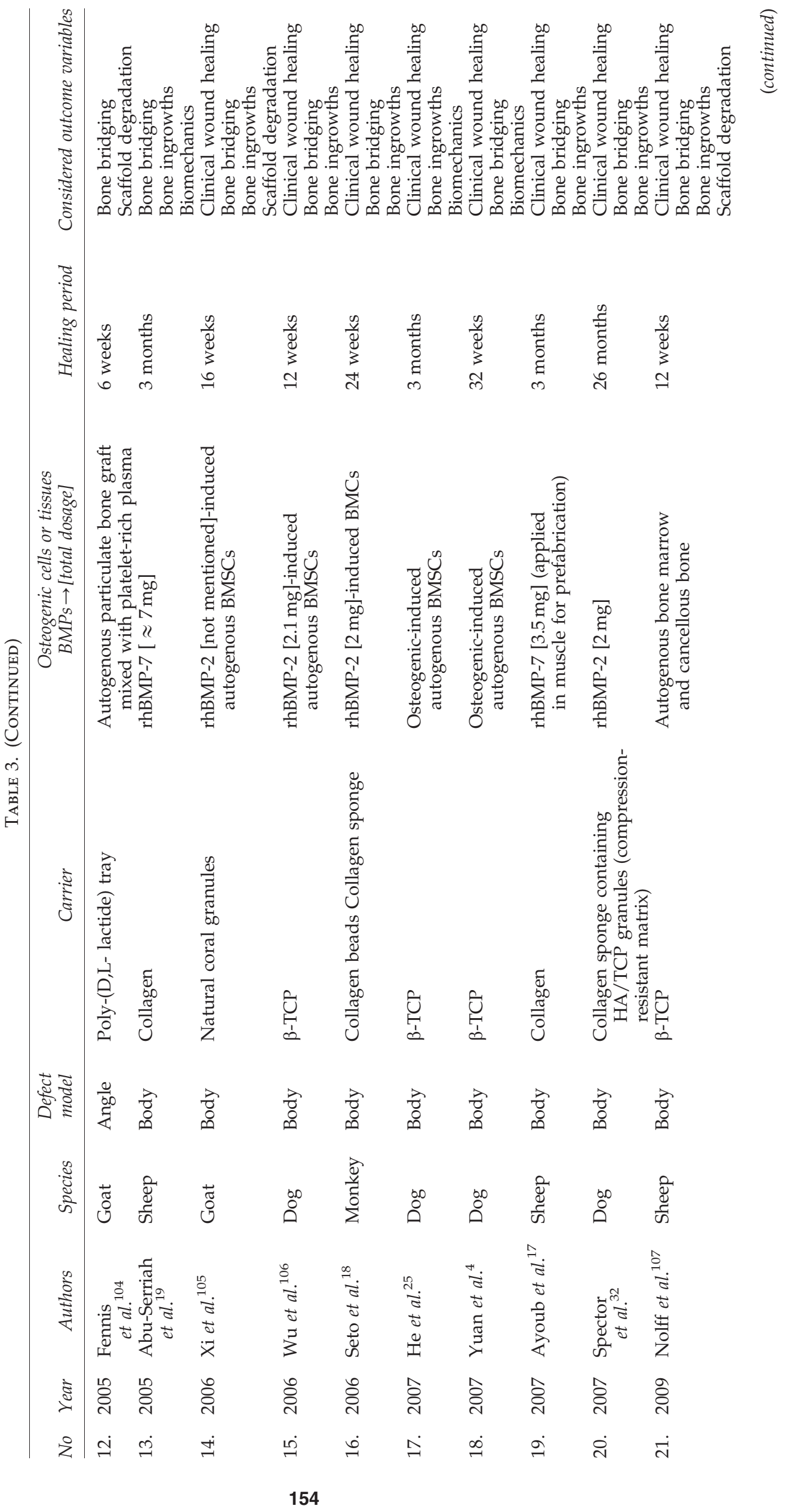




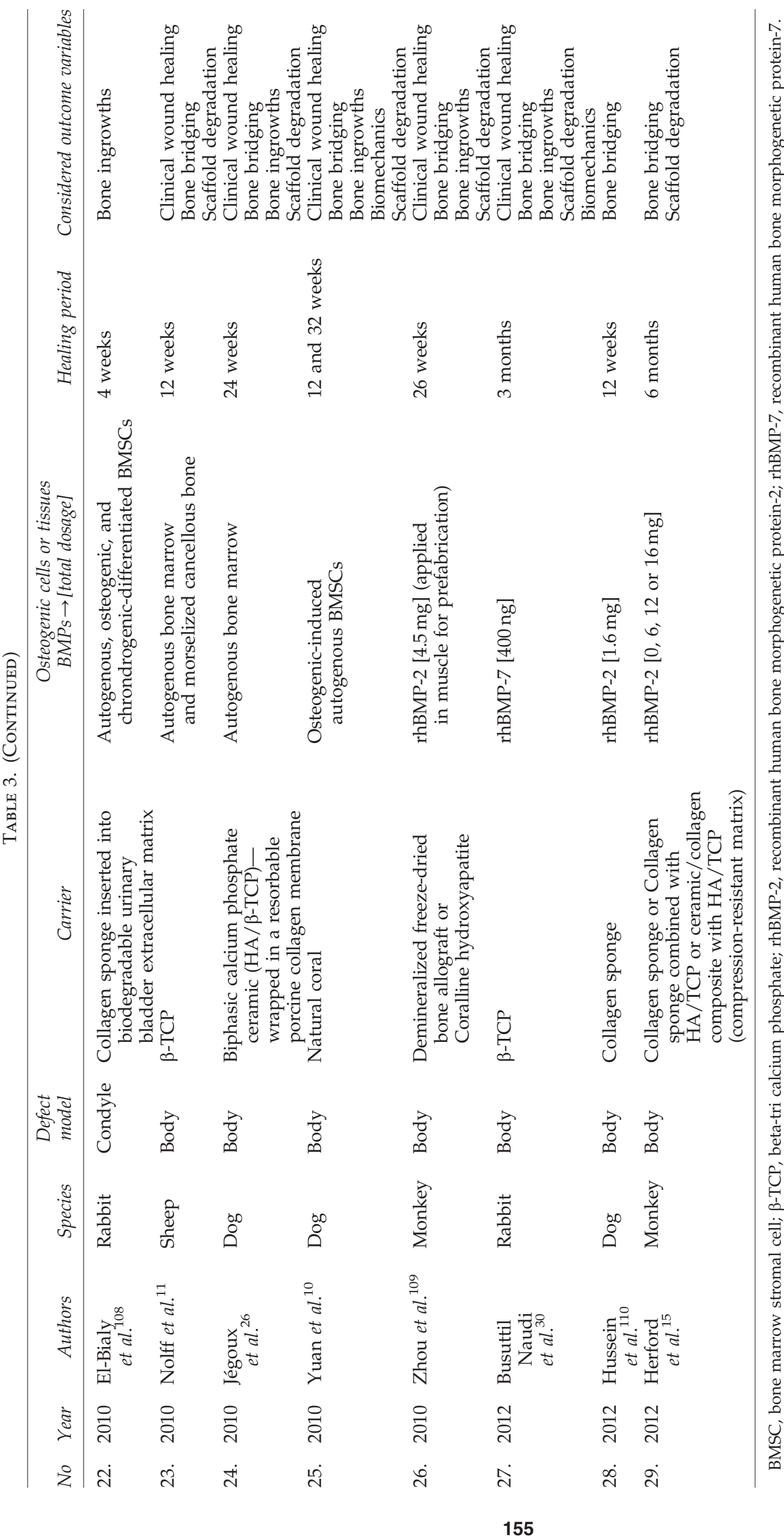






Besides, due to their compositional similarities to bone mineral, their excellent biocompatibility, osteoconductivity, as well as drug delivery potential, calcium phosphates, especially tricalcium phosphate and hydroxyapatite, are the most widely used bone substitutes in bone tissue engineering. ${ }^{127}$ Moreover, BMSCs seeded onto calcium phosphate scaffolds induced ectopic bone formation in a mice model. ${ }^{129}$

However, the currently presented favorable data for bone tissue-engineered constructs as compared with scaffolds alone have to be interpreted with caution. In principle, sample size and thereby statistical power of the reviewed preclinical in vivo experiments tended to be low. For example, the compared 12 weeks of bone bridging and bone ingrowths ${ }^{106}$ originate from only two animals/segmental defects without statistical analysis. Another example is the 3 months data. ${ }^{25}$ Their statistically significant better biomechanical results $(p<0.05)$ for tissue-engineered bone as compared with the scaffold alone originate from not more than three animals/segmental defects. Thus, with an assumed $\alpha$-error of 0.05 , post hoc analysis for, for example, compression strength reveals a statistical power as low as 0.385 . Furthermore, next to autogenous bone precursor cells or autogenous osteogenic tissues, bone morphogenetic proteins (i.e.: $r h B M P-2$ and $r h B M P-7$ ) were studied. Predominantly, $r h B M P-2$ and $r h B M P-7$ were combined with collagen/collagen composite scaffolds. However, a few papers examined combinations with poly-D,L-lactide coglycolic acid as well as calcium phosphate carriers. Regarding bone bridging, bone ingrowth, as well as biomechanical testing, these tissue-engineered approaches displayed some potential as an alternative to autograft bone for mandibular bone reconstruction in continuity defects. However, the published results were not uniform. For example, rhBMP-2 or rhBMP-7 combined with a bovine collagen type I carrier, ${ }^{17}$ polyglycolic co-lactic acid ${ }^{102}$ as well as demineralized freeze-dried bone allograft ${ }^{109}$ were not associated with predictable defect bridging. Overall, the published outcomes for bone morphogenetic proteins were not surprising and were in line with the reports for bone tissue engineering in general. The osteoinductive potential of BMP-2 and BMP- $7^{130}$ as well as the general importance of carrier selection in conjunction with growth factor application $^{15,115,131-133}$ are well known. In addition, for these reviewed preclinical in vivo experiments, sample size and thereby transferability tended to be low. For instance, the 3 months bone bridging data and the found wide range of mechanical properties of Abu-Serriah et al. ${ }^{19}$ were obtained from not more than six animals/segmental defects. Another good example is the publication of Boyne. ${ }^{29}$ Their 5 months of bone bridging and bone histology data originate from only three animals/segmental defects. Unfortunately, a meta-analytical approach to increase the power of statistical analysis by pooling the results of all retrieved available trials was not feasible. Research of results that are combined in a meta-analysis should preferably be done in a similar manner. As shown in Table 3, this is clearly not the case for the presently included papers. The publications, which were eligible for inclusion in the present study, display experimental variability for the utilized animal model, the anatomical site of reconstruction, the used bone tissue engineering approach, the number of enrolled animals/ defects, and the healing time after reconstruction. 
Apart from BMPs, alternative growth factors may serve as potential therapeutic agents to enhance bone and cartilage formation; for example, recombinant human platelet-derived growth factor (rhPDGF), transforming growth factor-beta (TGF- $\beta$ ), fibroblast growth factor, recombinant human growth/differentiation factor-5 (rhGDF-5), and insulin-like growth factor. ${ }^{134}$ PDGF is known to simulate angiogenesis through activation of the macrophages, ${ }^{134}$ which secrete factors cells to form new capillary sprouts. TGF- $\beta 1$ has been proved to promote cartilage regeneration. ${ }^{79}$ rhGDF- 5 has the potential to grow the same type of tissues as where it is naturally present. Its possibility of being used in a tissue engineering approach has been reported for the regeneration of dento-alveolar tissues. ${ }^{135,136}$

However, a single dose of an exogenous protein will not adequately induce a biologic response in compromised tissue conditions. Gene therapy is another concept in which genetic information is transferred into target cells. Subsequently, the cells synthesize the endogenous protein encoded by the gene. ${ }^{137}$ The process that involves the transfer of functional genetic information into the target cell is known as transduction. This is accomplished when the recombinant vector (virus) which contains the therapeutic DNA binds to the cell, usually via a receptor-mediated process, and then enters that cell. The DNA passes into the nucleus of the cell, where it may become integrated into the host genome or may remain extrachromosomal. The transduced cells can then produce and secrete the growth factor encoded by the DNA98-100. ${ }^{56,70}$ In this review, it was found that the use of gene therapy was being applied in the reconstruction of mandibular continuity defects in animals and humans. On the other hand, gene therapy has been reported for the repair of the mandibular condyle and temporomandibular joints and was found to support mineralized tissue formation. ${ }^{138-140}$

In the second part of the review, 11 papers, presenting human cases regarding tissue engineered reconstruction of mandibular continuity defects, were eventually included. The review included the reports on microvascular tissue transfer of prefabricated bones in the study. Although, these techniques belong to tissue regeneration, they are important for the reconstructive surgeon. Therefore, transplantation of tissue-engineered autogenous osteogenic tissues without additional application of osteoinductive BMPs or in combination with rhBMP-2/rhBMP-7 produced restored mandibular continuity in five out of six cases. Furthermore, in 29 out of 34 patients, the application of native human BMPs, xenogeneic BMPs, rhBMP-2, or rhBMP-7 without concomitant transplantation of autogenous osteogenic tissue was associated with complete bony defect bridging. Unfortunately, no direct comparison of the results with autogenous bone transplantation can be done due to lack of direct control. However, Herford and Cicciù ${ }^{120}$ stated that bone growth cytokines can be considered a predictable alternative to traditional grafting techniques. In general, these results were not astonishing and in line with the literature..$^{15,115,141-144}$ Thus, it might be assumed that these tissue-engineered approaches may have, in certain selected patients, some potential as an alternative to autograft bone for mandibular bone reconstruction in continuity defects. However, it should be underlined that until now only a few successfully treated cases have been published. Furthermore, to date, the clinical predictability has to be questioned. An additional issue is the limited license of the use of rhBMP-2 in oral and maxillofacial surgery. According to the Center for Devices and Radiological Health (CDRH) of the U.S. Food and Drug Administration (FDA), rhBMP-2 is not licensed for use in surgery of mandibular continuity defects and may only be applied for sinus augmentation and localized alveolar ridge augmentation.

\section{Conclusions}

The reviews showed a various study methodology, review period, and different control groups. Not all studies compared the finding with a reconstruction with autologous bone substitute. None of the human studies were performed as a randomized control trial study. Within the limits of this systematic approach to the literature regarding tissueengineered bone reconstruction in continuity defects of the mandible, we conclude that (1) published preclinical in vivo as well as clinical data are limited, and (2) tissue-engineered approaches demonstrate some clinical potential as an alternative to autograft bone. The future research in this area needs to include process evaluation research in order to define the characteristics contributing to the success and failure of any intervention.

\section{Acknowledgment}

This article was supported by the National Medical Research Council (NMRC), Singapore.

\section{Disclosure Statement}

No competing financial interests exist.

\section{References}

1. Wong, R.C., Tideman, H., Kin, L., and Merkx, M.A. Biomechanics of mandibular reconstruction: a review. Int J Oral Maxillofac Surg 39, 313, 2010.

2. Miles, B.A., Goldstein, D.P., Gilbert, R.W., and Gullane, P.J. Mandible reconstruction. Curr Opin Otolaryngol Head Neck Surg 18, 317, 2010.

3. Burchardt, H. The biology of bone graft repair. Clin Orthop Relat Res 28, 1983.

4. Yuan, J., Cui, L., Zhang, W.J., Liu, W., and Cao, Y. Repair of canine mandibular bone defects with bone marrow stromal cells and porous beta-tricalcium phosphate. Biomaterials 28, 1005, 2007.

5. Vaccaro, A.R. The role of the osteoconductive scaffold in synthetic bone graft. Orthopedics 25, s571, 2002.

6. Younger, E.M., and Chapman, M.W. Morbidity at bone graft donor sites. J Orthop Trauma 3, 192, 1989.

7. Wang, K.H., Inman, J.C., and Hayden, R.E. Modern concepts in mandibular reconstruction in oral and oropharyngeal cancer. Curr Opin Otolaryngol Head Neck Surg 19, 119, 2011.

8. Langer, R., and Vacanti, J.P. Tissue engineering. Science 260, 920, 1993.

9. Hutmacher, D.W. Scaffolds in tissue engineering bone and cartilage. Biomaterials 21, 2529, 2000.

10. Yuan, J., Zhang, W.J., Liu, G., Wei, M., Qi, Z.L., Liu, W., et al. Repair of canine mandibular bone defects with bone marrow stromal cells and coral. Tissue Eng Part A 16, 1385, 2010. 
11. Nolff, M.C., Kokemueller, H., Hauschild, G., Fehr, M., Bormann, K.H., Spalthoff, S., et al. Comparison of computed tomography and microradiography for graft evaluation after reconstruction of critical size bone defects using beta-tricalcium phosphate. J Craniomaxillofac Surg 38, 38, 2010.

12. Kneser, U., Schaefer, D.J., Polykandriotis, E., and Horch, R.E. Tissue engineering of bone: the reconstructive surgeon's point of view. J Cell Mol Med 10, 7, 2006.

13. Kretlow, J.D., and Mikos, A.G. 2007 AIChE Alpha Chi Sigma Award: from material to tissue: biomaterial development, scaffold fabrication, and tissue engineering. AIChE J 54, 3048, 2008.

14. Rezwan, K., Chen, Q.Z., Blaker, J.J., and Boccaccini, A.R. Biodegradable and bioactive porous polymer/inorganic composite scaffolds for bone tissue engineering. Biomaterials 27, 3413, 2006.

15. Herford, A.S., Lu, M., Buxton, A.N., Kim, J., Henkin, J., Boyne, P.J., et al. Recombinant human bone morphogenetic protein 2 combined with an osteoconductive bulking agent for mandibular continuity defects in nonhuman primates. J Oral Maxillofac Surg 70, 703, 2012.

16. Kontaxis, A., Abu-Serriah, M., Ayoub, A.F., and Barbenel, J.C. Mechanical testing of recombinant human bone morphogenetic protein-7 regenerated bone in sheep mandibles. Proc Inst Mech Eng H 218, 381, 2004.

17. Ayoub, A., Challa, S.R., Abu-Serriah, M., McMahon, J., Moos, K., Creanor, S., et al. Use of a composite pedicled muscle flap and rhBMP-7 for mandibular reconstruction. Int J Oral Maxillofac Surg 36, 1183, 2007.

18. Seto, I., Marukawa, E., and Asahina, I. Mandibular reconstruction using a combination graft of rhBMP-2 with bone marrow cells expanded in vitro. Plast Reconstr Surg 117, 902, 2006.

19. Abu-Serriah, M., Kontaxis, A., Ayoub, A., Harrison, J., Odell, E., and Barbenel, J. Mechanical evaluation of mandibular defects reconstructed using osteogenic protein-1 (rhOP-1) in a sheep model: a critical analysis. Int J Oral Maxillofac Surg 34, 287, 2005.

20. Cancedda, R., Mastrogiacomo, M., Bianchi, G., Derubeis, A., Muraglia, A., and Quarto, R. Bone marrow stromal cells and their use in regenerating bone. Novartis Found Symp 249, 133, 2003.

21. Foschi, F., Conserva, E., Pera, P., Canciani, B., Cancedda, R., and Mastrogiacomo, M. Graft materials and bone marrow stromal cells in bone tissue engineering. J Biomater Appl 26, 1035, 2012.

22. Zomorodian, E., and Baghaban Eslaminejad, M. Mesenchymal stem cells as a potent cell source for bone regeneration. Stem Cells Int 2012, 980353, 2012.

23. Cooper, L.F., Harris, C.T., Bruder, S.P., Kowalski, R., and Kadiyala, S. Incipient analysis of mesenchymal stem-cellderived osteogenesis. J Dent Res 80, 314, 2001.

24. Yuan, J., Liu, G.P., Chai, G., Liu, B., Xu, F., Cui, L., et al. [Pilot study of using autologous bone marrow stromal cells and coral to repair canine segmental mandibular defects]. Zhonghua Zheng Xing Wai Ke Za Zhi 23, 51, 2007.

25. He, Y., Zhang, Z.Y., Zhu, H.G., Qiu, W., Jiang, X., and Guo, W. Experimental study on reconstruction of segmental mandible defects using tissue engineered bone combined bone marrow stromal cells with three-dimensional tricalcium phosphate. J Craniofac Surg 18, 800, 2007.

26. Jegoux, F., Goyenvalle, E., Cognet, R., Malard, O., Moreau, F., Daculsi, G., et al. Mandibular segmental defect re- generated with macroporous biphasic calcium phosphate, collagen membrane, and bone marrow graft in dogs. Arch Otolaryngol Head Neck Surg 136, 971, 2010.

27. Schilephake, H. Bone growth factors in maxillofacial skeletal reconstruction. Int J Oral Maxillofac Surg 31, 469, 2002.

28. Devescovi, V., Leonardi, E., Ciapetti, G., and Cenni, E. Growth factors in bone repair. Chir Organi Mov 92, 161, 2008.

29. Boyne, P.J. Animal studies of application of rhBMP-2 in maxillofacial reconstruction. Bone 19, 83S, 1996.

30. Busuttil Naudi, K., Ayoub, A., McMahon, J., Di Silvio, L., Lappin, D., Hunter, K.D., et al. Mandibular reconstruction in the rabbit using beta-tricalcium phosphate (beta-TCP) scaffolding and recombinant bone morphogenetic protein 7 (rhBMP-7)-Histological, radiographic and mechanical evaluations. J Craniomaxillofac Surg 40, e461, 2012.

31. Seto, I., Tachikawa, N., Mori, M., Hoshino, S., Marukawa, E., Asahina, I., et al. Restoration of occlusal function using osseointegrated implants in the canine mandible reconstructed by rhBMP-2. Clin Oral Implants Res 13, 536, 2002.

32. Spector, D.I., Keating, J.H., and Boudrieau, R.J. Immediate mandibular reconstruction of a $5 \mathrm{~cm}$ defect using rhBMP-2 after partial mandibulectomy in a dog. Vet Surg 36, 752, 2007.

33. Wang, H., Springer, I.N., Schildberg, H., Acil, Y., Ludwig, K., Rueger, D.R., et al. Carboxymethylcellulose-stabilized collagenous rhOP-1 device-a novel carrier biomaterial for the repair of mandibular continuity defects. J Biomed Mater Res Part A 68, 219, 2004.

34. Ikada, Y. Challenges in tissue engineering. J R Soc Interface 3, 589, 2006.

35. Kanczler, J.M., and Oreffo, R.O. Osteogenesis and angiogenesis: the potential for engineering bone. Eur Cells Mater 15, 100, 2008.

36. Schliephake, H., Jamil, M.U., and Knebel, J.W. Experimental reconstruction of the mandible using polylactic acid tubes and basic fibroblast growth factor in alloplastic scaffolds. J Oral Maxillofac Surg 56, 616, 1998.

37. Fisher, J.P., Lalani, Z., Demian, N., Wong, M.E.K., and Mikos, A.G. Engineering in Medicine and Biology. 24th Annual Conference and the Annual Fall Meeting of the Biomedical Engineering Society EMBS/BMES Conference, 2002. Proceedings of the Second Joint, IEEE Conference Publications 2002 Oct 1, pp. 827-828.

38. Chu, T.M., Orton, D.G., Hollister, S.J., Feinberg, S.E., and Halloran, J.W. Mechanical and in vivo performance of hydroxyapatite implants with controlled architectures. Biomaterials 23, 1283, 2002.

39. Gröger, A., Klaring, S., Merten, H.A., Holste, J., Kaps, C., and Sittinger, M. Tissue engineering of bone for mandibular augmentation in immunocompetent minipigs: preliminary study. Scand J Plast Reconstr Surg Hand Surg 37, 129, 2003.

40. Nakahara, T., Nakamura, T., Kobayashi, E., Inoue, M., Shigeno, K., Tabata, Y., et al. Novel approach to regeneration of periodontal tissues based on in situ tissue engineering: effects of controlled release of basic fibroblast growth factor from a sandwich membrane. Tissue Eng 9, 153, 2003.

41. Abukawa, H., Shin, M., Williams, W.B., Vacanti, J.P., Kaban, L.B., and Troulis, M.J. Reconstruction of mandibular defects with autologous tissue-engineered bone. J Oral Maxillofac Surg 62, 601, 2004.

42. Yamada, Y., Ueda, M., Hibi, H., and Nagasaka, T. Translational research for injectable tissue-engineered bone re- 
generation using mesenchymal stem cells and platelet-rich plasma: from basic research to clinical case study. Cell Transplant 13, 343, 2004.

43. Yamada, Y., Ueda, M., Naiki, T., and Nagasaka, T. Tissueengineered injectable bone regeneration for osseointegrated dental implants. Clin Oral Implants Res 15, 589, 2004.

44. Ito, K., Yamada, Y., Nagasaka, T., Baba, S., and Ueda, M. Osteogenic potential of injectable tissue-engineered bone: a comparison among autogenous bone, bone substitute (Biooss), platelet-rich plasma, and tissue-engineered bone with respect to their mechanical properties and histological findings. J Biomed Mater Res Part A 73, 63, 2005.

45. Li, Z., and Li, Z.B. Repair of mandible defect with tissue engineering bone in rabbits. ANZ J Surg 75, 1017, 2005.

46. Marei, M.K., Nouh, S.R., Saad, M.M., and Ismail, N.S. Preservation and regeneration of alveolar bone by tissueengineered implants. Tissue Eng 11, 715, 2005.

47. Meyer, U., Buchter, A., Hohoff, A., Stoffels, E., Szuwart, T., Runte, C., et al. Image-based extracorporeal tissue engineering of individualized bone constructs. Int J Oral Maxillofac Implants 20, 882, 2005.

48. Ren, T., Ren, J., Jia, X., and Pan, K. The bone formation in vitro and mandibular defect repair using PLGA porous scaffolds. J Biomed Mater Res Part A 74, 562, 2005.

49. Ito, K., Yamada, Y., Naiki, T., and Ueda, M. Simultaneous implant placement and bone regeneration around dental implants using tissue-engineered bone with fibrin glue, mesenchymal stem cells and platelet-rich plasma. Clin Oral Implants Res 17, 579, 2006.

50. Mylonas, D., Vidal, M.D., De Kok, I.J., Moriarity, J.D., and Cooper, L.F. Investigation of a thermoplastic polymeric carrier for bone tissue engineering using allogeneic mesenchymal stem cells in granular scaffolds. J Prosthodont 16, 421, 2007.

51. Ren, J., Ren, T., Zhao, P., Huang, Y., and Pan, K. Repair of mandibular defects using MSCs-seeded biodegradable polyester porous scaffolds. J Biomater Sci Polym Ed 18, 505, 2007.

52. Rai, B., Ho, K.H., Lei, Y., Si-Hoe, K.M., Jeremy Teo, C.M., Yacob, K.B., et al. Polycaprolactone- $20 \%$ tricalcium phosphate scaffolds in combination with platelet-rich plasma for the treatment of critical-sized defects of the mandible: a pilot study. J Oral Maxillofac Surg 65, 2195, 2007.

53. Wang, H., Li, Y., Zuo, Y., Li, J., Ma, S., and Cheng, L. Biocompatibility and osteogenesis of biomimetic nanohydroxyapatite/polyamide composite scaffolds for bone tissue engineering. Biomaterials 28, 3338, 2007.

54. Zhang, Y., Song, J., Shi, B., Wang, Y., Chen, X., Huang, C., et al. Combination of scaffold and adenovirus vectors expressing bone morphogenetic protein-7 for alveolar bone regeneration at dental implant defects. Biomaterials 28, 4635, 2007.

55. Kuznetsov, S.A., Huang, K.E., Marshall, G.W., Robey, P.G., and Mankani, M.H. Long-term stable canine mandibular augmentation using autologous bone marrow stromal cells and hydroxyapatite/tricalcium phosphate. Biomaterials 29, 4211, 2008.

56. Tang, Y., Tang, W., Lin, Y., Long, J., Wang, H., Liu, L., et al. Combination of bone tissue engineering and BMP-2 gene transfection promotes bone healing in osteoporotic rats. Cell Biol Int 32, 1150, 2008.

57. Wang, C., Y., Wang, W., Zhang, L., Ai, H., J., et al. Nanohydroxyapatite/collagen/poly(L-lactic acid) co-cultured with bone marrow stromal cells for repair of rabbit mandibular defect. J Clin Rehab Tissue Eng Res 12, 9762, 2008.
58. Abukawa, H., Zhang, W., Young, C.S., Asrican, R., Vacanti, J.P., Kaban, L.B., et al. Reconstructing mandibular defects using autologous tissue-engineered tooth and bone constructs. J Oral Maxillofac Surg 67, 335, 2009.

59. Appleford, M.R., Oh, S., Oh, N., and Ong, J.L. In vivo study on hydroxyapatite scaffolds with trabecular architecture for bone repair. J Biomed Mater Res Part A 89, 1019, 2009.

60. d'Aquino, R., De Rosa, A., Lanza, V., Tirino, V., Laino, L., Graziano, A., et al. Human mandible bone defect repair by the grafting of dental pulp stem/progenitor cells and collagen sponge biocomplexes. Eur Cells Mater 18, 75, 2009.

61. Guo, H., Su, J., Wei, J., Kong, H., and Liu, C. Biocompatibility and osteogenicity of degradable Ca-deficient hydroxyapatite scaffolds from calcium phosphate cement for bone tissue engineering. Acta Biomater 5, 268, 2009.

62. Jiang, X., Zhao, J., Wang, S., Sun, X., Zhang, X., Chen, J., et al. Mandibular repair in rats with premineralized silk scaffolds and BMP-2-modified bMSCs. Biomaterials 30, 4522, 2009.

63. Schliephake, H., Zghoul, N., Jager, V., van Griensven, M., Zeichen, J., Gelinsky, M., et al. Bone formation in trabecular bone cell seeded scaffolds used for reconstruction of the rat mandible. Int J Oral Maxillofac Surg 38, 166, 2009.

64. Schuckert, K.H., Jopp, S., and Teoh, S.H. Mandibular defect reconstruction using three-dimensional polycaprolactone scaffold in combination with platelet-rich plasma and recombinant human bone morphogenetic protein-2: de novo synthesis of bone in a single case. Tissue Eng Part A 15, 493, 2009.

65. Shi, S., Cheng, X., Wang, J., Zhang, W., Peng, L., and Zhang, Y. RhBMP-2 microspheres-loaded chitosan/collagen scaffold enhanced osseointegration: an experiment in dog. J Biomater Appl 23, 331, 2009.

66. Wang, S., Zhang, Z., Zhao, J., Zhang, X., Sun, X., Xia, L., et al. Vertical alveolar ridge augmentation with beta-tricalcium phosphate and autologous osteoblasts in canine mandible. Biomaterials 30, 2489, 2009.

67. Yao, J., Li, X., Bao, C., Fan, H., Zhang, X., and Chen, Z. A novel technique to reconstruct a boxlike bone defect in the mandible and support dental implants with In vivo tissueengineered bone. J Biomed Mater Res Part B Appl Biomater 91, 805, 2009.

68. Yoshimi, R., Yamada, Y., Ito, K., Nakamura, S., Abe, A., Nagasaka, T., et al. Self-assembling peptide nanofiber scaffolds, platelet-rich plasma, and mesenchymal stem cells for injectable bone regeneration with tissue engineering. J Craniofac Surg 20, 1523, 2009.

69. Zhang, H., Ye, X.J., and Li, J.S. Preparation and biocompatibility evaluation of apatite/wollastonite-derived porous bioactive glass ceramic scaffolds. Biomed Mater 4, 045007, 2009.

70. Zhang, Y., Shi, B., Li, C., Wang, Y., Chen, Y., Zhang, W., et al. The synergetic bone-forming effects of combinations of growth factors expressed by adenovirus vectors on chitosan/collagen scaffolds. J Control Release 136, 172, 2009.

71. Zhao, J., Zhang, Z., Wang, S., Sun, X., Zhang, X., Chen, J., et al. Apatite-coated silk fibroin scaffolds to healing mandibular border defects in canines. Bone 45, 517, 2009.

72. Zheng, Y., Liu, Y., Zhang, C.M., Zhang, H.Y., Li, W.H., Shi, S., et al. Stem cells from deciduous tooth repair mandibular defect in swine. J Dent Res 88, 249, 2009.

73. Gallego, L., Junquera, L., Garcia, E., Garcia, V., AlvarezViejo, M., Costilla, S., et al. Repair of rat mandibular bone 
defects by alveolar osteoblasts in a novel plasma-derived albumin scaffold. Tissue Eng Part A 16, 1179, 2010.

74. Huang, Y., Ren, J., Ren, T., Gu, S., Tan, Q., Zhang, L., et al. Bone marrow stromal cells cultured on poly (lactideco-glycolide)/nano-hydroxyapatite composites with chemical immobilization of Arg-Gly-Asp peptide and preliminary bone regeneration of mandibular defect thereof. J Biomed Mater Res Part A 95, 993, 2010.

75. Li, J., Li, Y., Ma, S., Gao, Y., Zuo, Y., and Hu, J. Enhancement of bone formation by BMP-7 transduced MSCs on biomimetic nano-hydroxyapatite/polyamide composite scaffolds in repair of mandibular defects. J Biomed Mater Res Part A 95, 973, 2010.

76. Parrilla, C., Lattanzi, W., Rita Fetoni, A., Bussu, F., Pola, E., and Paludetti, G. Ex vivo gene therapy using autologous dermal fibroblasts expressing hLMP3 for rat mandibular bone regeneration. Head Neck 32, 310, 2010.

77. Ribeiro, F.V., Suaid, F.F., Ruiz, K.G., Rodrigues, T.L., Carvalho, M.D., Nociti, F.H., et al. Peri-implant reconstruction using autologous periosteum-derived cells and guided bone regeneration. J Clin Periodontol 37, 1128, 2010.

78. Zhao, J., Hu, J., Wang, S., Sun, X., Xia, L., Zhang, X., et al. Combination of beta-TCP and BMP-2 gene-modified bMSCs to heal critical size mandibular defects in rats. Oral Dis 16, 46, 2010.

79. Dormer, N.H., Busaidy, K., Berkland, C.J., and Detamore, M.S. Osteochondral interface regeneration of rabbit mandibular condyle with bioactive signal gradients. J Oral Maxillofac Surg 69, e50, 2011.

80. Kohgo, T., Yamada, Y., Ito, K., Yajima, A., Yoshimi, R., Okabe, K., et al. Bone regeneration with self-assembling peptide nanofiber scaffolds in tissue engineering for osseointegration of dental implants. Int J Periodontics Restorative Dent 31, e9, 2011.

81. Ito, K., Yamada, Y., Nakamura, S., and Ueda, M. Osteogenic potential of effective bone engineering using dental pulp stem cells, bone marrow stem cells, and periosteal cells for osseointegration of dental implants. Int J Oral Maxillofac Implants 26, 947, 2011.

82. Parrilla, C., Saulnier, N., Bernardini, C., Patti, R., Tartaglione, T., Fetoni, A.R., et al. Undifferentiated human adipose tissue-derived stromal cells induce mandibular bone healing in rats. Arch Otolaryngol Head Neck Surg 137, 463, 2011.

83. Yamada, Y., Ito, K., Nakamura, S., Ueda, M., and Nagasaka, T. Promising cell-based therapy for bone regeneration using stem cells from deciduous teeth, dental pulp, and bone marrow. Cell Transplant 20, 1003, 2011.

84. Zhu, S., Zhang, B., Man, C., Ma, Y., and Hu, J. NEL-like molecule-1-modified bone marrow mesenchymal stem cells / poly lactic-co-glycolic acid composite improves repair of large osteochondral defects in mandibular condyle. Osteoarthritis Cartilage 19, 743, 2011.

85. Yeo, A., Cheok, C., Teoh, S.H., Zhang, Z.Y., Buser, D., and Bosshardt, D.D. Lateral ridge augmentation using a PCLTCP scaffold in a clinically relevant but challenging micropig model. Clin Oral Implants Res 23, 1322, 2012.

86. Vahabi, S., Amirizadeh, N., Shokrgozar, M.A., Mofeed, R., Mashhadi, A., Aghaloo, M., et al. A comparison between the efficacy of Bio-Oss, hydroxyapatite tricalcium phosphate and combination of mesenchymal stem cells in inducing bone regeneration. Chang Gung Med J 35, 28, 2012.

87. Zhou, Y., Xu, L., Zhang, X.M., Zhao, Y.H., Wei, S.C., and Zhai, M.L. Radiation synthesis of gelatin/CM-chitosan/ beta-tricalcium phosphate composite scaffold for bone tissue engineering. Mater Sci Eng C-Mater 32, 994, 2012.

88. Zou, D.H., He, J.C., Zhang, K., Dai, J.W., Zhang, W.J., Wang, S.Y., et al. The bone-forming effects of HIF-1 alphatransduced BMSCs promote osseointegration with dental implant in canine mandible. PLoS One 7, e32355, 2012.

89. Schliephake, H., and Lagner, M. Reconstruction of the mandible by prefabricated autogenous bone grafts-An experimental study in minipigs. Int J Oral Maxillofac Surg 26, 244, 1997.

90. Terheyden, H., Knak, C., Jepsen, S., Palmie, S., and Rueger, D.R. Mandibular reconstruction with a prefabricated vascularized bone graft using recombinant human osteogenic protein-1: an experimental study in miniature pigs. Part I: prefabrication. Int J Oral Maxillofac Surg 30, 373, 2001.

91. Abu-Serriah, M., Ayoub, A., Boyd, J., Paterson, C., and Wray, D. The role of ultrasound in monitoring reconstruction of mandibular continuity defects using osteogenic protein-1 (rhOP-1). Int J Oral Maxillofac Surg 32, 619, 2003.

92. Marei, M.K., Nouh, S.R., Fata, M.M., and Faramawy, A.M. Fabrication of polymer root form scaffolds to be utilized for alveolar bone regeneration. Tissue Eng 9, 713, 2003.

93. Young, S., Bashoura, A.G., Borden, T., Baggett, L.S., Jansen, J.A., Wong, M., et al. Development and characterization of a rabbit alveolar bone nonhealing defect model. J Biomed Mater Res Part A 86, 182, 2008.

94. Ko, E.K., Jeong, S.I., Rim, N.G., Lee, Y.M., Shin, H., Lee, B.K. In vitro osteogenic differentiation of human mesenchymal stem cells and in vivo bone formation in composite nanofiber meshes. Tissue Eng Part A 14, 2105, 2008.

95. Glied, A.N., and Kraut, R.A. Off-label use of rhBMP-2 for reconstruction of critical-sized mandibular defects. N Y State Dent J 76, 32, 2010.

96. Matsushima, S., Isogai, N., Jacquet, R., Lowder, E., Tokui, T., and Landis, W.J. The nature and role of periosteum in bone and cartilage regeneration. Cells Tissues Organs 194, 320, 2011.

97. Toriumi, D.M., Kotler, H.S., Luxenberg, D.P., Holtrop, M.E., and Wang, E.A. Mandibular reconstruction with a recombinant bone-inducing factor. Functional, histologic, and biomechanical evaluation. Arch Otolaryngol Head Neck Surg 117, 1101, 1991.

98. Toriumi, D.M., O'Grady, K., Horlbeck, D.M., Desai, D., Turek, T.J., and Wozney, J. Mandibular reconstruction using bone morphogenetic protein 2: long-term follow-up in a canine model. Laryngoscope 109, 1481, 1999.

99. Boyne, P.J., Nakamura, A., and Shabahang, S. Evaluation of the long-term effect of function on rhBMP-2 regenerated hemimandibulectomy defects. Br J Oral Maxillofac Surg 37, 344, 1999.

100. Schliephake, H., Knebel, J.W., Aufderheide, M., and Tauscher, M. Use of cultivated osteoprogenitor cells to increase bone formation in segmental mandibular defects: an experimental pilot study in sheep. Int J Oral Maxillofac Surg 30, 531, 2001.

101. Boyne, P.J. Application of bone morphogenetic proteins in the treatment of clinical oral and maxillofacial osseous defects. J Bone Joint Surg Am 83-A Suppl 1, S146, 2001.

102. Seto, I., Asahina, I., Oda, M., and Enomoto, S. Reconstruction of the primate mandible with a combination graft of recombinant human bone morphogenetic protein-2 and bone marrow. J Oral Maxillofac Surg 59, 53, 2001.

103. Marukawa, E., Asahina, I., Oda, M., Seto, I., Alam, M., and Enomoto, S. Functional reconstruction of the non-human 
primate mandible using recombinant human bone morphogenetic protein-2. Int J Oral Maxillofac Surg 31, 287, 2002.

104. Fennis, J.P., Stoelinga, P.J., Merkx, M.A., and Jansen, J.A. Reconstruction of the mandible with a poly(D,L-lactide) scaffold, autogenous corticocancellous bone graft, and autogenous platelet-rich plasma: an animal experiment. Tissue Eng 11, 1045, 2005.

105. Xi, Q., Bu, R.F., Liu, H.C., and Mao, T.Q. Reconstruction of caprine mandibular segmental defect by tissue engineered bone reinforced by titanium reticulum. Chin J Traumatol 9, 67, 2006.

106. Wu, W., Chen, X., Mao, T., Chen, F., and Feng, X. Bone marrow-derived osteoblasts seeded into porous betatricalcium phosphate to repair segmental defect in canine's mandibula. Ulus Travma Acil Cerrahi Derg 12, 268, 2006.

107. Nolff, M.C., Gellrich, N.C., Hauschild, G., Fehr, M., Bormann, K.H., Rohn, K., et al. Comparison of two betatricalcium phosphate composite grafts used for reconstruction of mandibular critical size bone defects. Vet Comp Orthop Traumatol 22, 96, 2009.

108. El-Bialy, T., Uludag, H., Jomha, N., and Badylak, S.F. In vivo ultrasound-assisted tissue-engineered mandibular condyle: a pilot study in rabbits. Tissue Eng Part C Methods 16, 1315, 2010.

109. Zhou, M., Peng, X., Mao, C., Xu, F., Hu, M., and Yu, G.Y. Primate mandibular reconstruction with prefabricated, vascularized tissue-engineered bone flaps and recombinant human bone morphogenetic protein-2 implanted in situ. Biomaterials 31, 4935, 2010.

110. Hussein, K.A., Zakhary, I.E., Elawady, A.R., Emam, H.A., Sharawy, M., Baban, B., et al. Difference in soft tissue response between immediate and delayed delivery suggests a new mechanism for recombinant human bone morphogenetic protein 2 action in large segmental bone defects. Tissue Eng Part A 18, 665, 2012.

111. Moghadam, H.G., Urist, M.R., Sandor, G.K., and Clokie, C.M. Successful mandibular reconstruction using a BMP bioimplant. J Craniofac Surg 12, 119, 2001.

112. Ferretti, C., and Ripamonti, U. Human segmental mandibular defects treated with naturally derived bone morphogenetic proteins. J Craniofac Surg 13, 434, 2002.

113. Warnke, P.H., Springer, I.N., Wiltfang, J., Acil, Y., Eufinger, H., Wehmoller, M., et al. Growth and transplantation of a custom vascularised bone graft in a man. Lancet 364, 766, 2004.

114. Warnke, P.H., Wiltfang, J., Springer, I., Acil, Y., Bolte, H., Kosmahl, M., et al. Man as living bioreactor: fate of an exogenously prepared customized tissue-engineered mandible. Biomaterials 27, 3163, 2006.

115. Herford, A.S., Boyne, P.J., and Williams, R.P. Clinical applications of rhBMP-2 in maxillofacial surgery. J Calif Dent Assoc 35, 335, 2007.

116. Clokie, C.M., and Sandor, G.K. Reconstruction of 10 major mandibular defects using bioimplants containing BMP-7. J Can Dent Assoc 74, 67, 2008.

117. Carter, T.G., Brar, P.S., Tolas, A., and Beirne, O.R. Off-label use of recombinant human bone morphogenetic protein-2 (rhBMP-2) for reconstruction of mandibular bone defects in humans. J Oral Maxillofac Surg 66, 1417, 2008.

118. Herford, A.S., and Boyne, P.J. Reconstruction of mandibular continuity defects with bone morphogenetic protein-2 (rhBMP-2). J Oral Maxillofac Surg 66, 616, 2008.

119. Kokemueller, H., Spalthoff, S., Nolff, M., Tavassol, F., Essig, H., Stuehmer, C., et al. Prefabrication of vascularized bioartificial bone grafts in vivo for segmental mandibular reconstruction: experimental pilot study in sheep and first clinical application. Int J Oral Maxillofac Surg 39, 379, 2010.

120. Herford, A.S., and Cicciù, M. Recombinant human bone morphogenetic protein type 2 jaw reconstruction in patients affected by giant cell tumor. J Craniofac Surg 21, 1970, 2010.

121. Cicciù, M., Herford, A.S., Stoffella, E., Cervino, G., and Cicciù, D. Protein-signaled guided bone regeneration using titanium mesh and Rh-BMP2 in oral surgery: a case report involving left mandibular reconstruction after tumor resection. Open Dent J 6, 51, 2012.

122. Levi, B., Glotzbach, J.P., Wong, V.W., Nelson, E.R., Hyun, J., Wan, D.C., et al. Stem cells: update and impact on craniofacial surgery. J Craniofac Surg 23, 319, 2012.

123. Yeatts, A.B., and Fisher, J.P. Bone tissue engineering bioreactors: dynamic culture and the influence of shear stress. Bone 48, 171, 2011.

124. Ciapetti, G. Vitro model to study bone tissue engineering. J Bone Joint Surg Br 87-B, SUPP I57, 2005.

125. Rauh, J., Milan, F., Gunther, K.P., and Stiehler, M. Bioreactor systems for bone tissue engineering. Tissue Eng Part B Rev 17, 263, 2011.

126. Fisher, J.P., and Raddi, A.H. Functional tissue engineering of bone: signals and scaffolds. Top Tissue Eng 5, 14, 2003.

127. Bose, S., and Tarafder, S. Calcium phosphate ceramic systems in growth factor and drug delivery for bone tissue engineering: a review. Acta Biomater 8, 1401, 2012.

128. Khan, W.S., Rayan, F., Dhinsa, B.S., and Marsh, D. An Osteoconductive, osteoinductive, and osteogenic tissueengineered product for trauma and orthopaedic surgery: how far are we? Stem Cells Int 2012, 236231, 2012.

129. Martin, I., Muraglia, A., Campanile, G., Cancedda, R., and Quarto, R. Fibroblast growth factor-2 supports ex vivo expansion and maintenance of osteogenic precursors from human bone marrow. Endocrinology 138, 4456, 1997.

130. Cheng, H., Jiang, W., Phillips, F.M., Haydon, R.C., Peng, Y., Zhou, L., et al. Osteogenic activity of the fourteen types of human bone morphogenetic proteins (BMPs). J Bone Joint Surg Am 85-A, 1544, 2003.

131. Sigurdsson, T.J., Nygaard, L., Tatakis, D.N., Fu, E., Turek, T.J., Jin, L., et al. Periodontal repair in dogs: evaluation of rhBMP-2 carriers. Int J Periodontics Restorative Dent 16, $524,1996$.

132. Wikesjo, U.M., Razi, S.S., Sigurdsson, T.J., Tatakis, D.N., Lee, M.B., Ongpipattanakul, B., et al. Periodontal repair in dogs: effect of recombinant human transforming growth factor-beta1 on guided tissue regeneration. J Clin Periodontol 25, 475, 1998.

133. Barboza, E.P., Duarte, M.E., Geolas, L., Sorensen, R.G., Riedel, G.E., and Wikesjo, U.M. Ridge augmentation following implantation of recombinant human bone morphogenetic protein-2 in the dog. J Periodontol 71, 488, 2000.

134. Lieberman, J.R., Daluiski, A., and Einhorn, T.A. The role of growth factors in the repair of bone. Biology and clinical applications. J Bone Joint Surg Am 84-A, 1032, 2002.

135. Lee, J.S., Wikesjo, U.M., Jung, U.W., Choi, S.H., Pippig, S., Siedler, M., et al. Periodontal wound healing/regeneration following implantation of recombinant human growth/ differentiation factor- 5 in a beta-tricalcium phosphate carrier into one-wall intrabony defects in dogs. J Clin Periodontol 37, 382, 2010.

136. Leknes, K.N., Yang, J., Qahash, M., Polimeni, G., Susin, C., and Wikesjo, U.M. Alveolar ridge augmentation using 
implants coated with recombinant human growth/differentiation factor -5 (rhGDF-5). Radiographic observations. Clin Oral Implants Res 2012 [Epub ahead of print]; DOI: $10.1111 /$ j.1600-0501.2012.02564.x.

137. Scheller, E.L., Villa-Diaz, L.G., and Krebsbach, P.H. Gene therapy: implications for craniofacial regeneration. J Craniofac Surg 23, 2012.

138. Li, Q., Dai, J., and Rabie, A.B. Recombinant adeno-associated virus serotype 2 (rAAV2)-An efficient vector for gene delivery in condylar cartilage, glenoid fossa and TMJ disc in an experimental study in vivo. Arch Oral Biol 54, 943, 2009.

139. Dai, J., and Rabie, A.B. Gene therapy to enhance condylar growth using rAAV-VEGF. Angle Orthod 78, 89, 2008.

140. Rabie, A.B., Dai, J., and Xu, R. Recombinant AAV-mediated VEGF gene therapy induces mandibular condylar growth. Gene Ther 14, 972, 2007.

141. Herford, A.S. rhBMP-2 as an option for reconstructing mandibular continuity defects. J Oral Maxillofac Surg 67, 2679, 2009.

142. Friedlaender, G.E., Perry, C.R., Cole, J.D., Cook, S.D., Cierny, G., Muschler, G.F., et al. Osteogenic protein-1 (bone morphogenetic protein-7) in the treatment of tibial nonunions. J Bone Joint Surg Am 83-A Suppl 1, S151, 2001.
143. Warnke, P.H., and Coren, A.J. First experiences with recombinant human bone morphogenetic protein 7 (osteogenic protein 1) in a human case in maxillofacial surgery. Plast Reconstr Surg 111, 2471, 2003.

144. Jung, R.E., Thoma, D.S., and Hammerle, C.H. Assessment of the potential of growth factors for localized alveolar ridge augmentation: a systematic review. J Clin Periodontol 35, 255, 2008.

Address correspondence to: Nattharee Chanchareonsook, DDS, MDS Department of Oral and Maxillofacial Surgery National Dental Centre Singapore 5 Second Hospital Ave. Singapore 168938 Singapore

E-mail: cnattharee@yahoo.com

Received: February 22, 2013 Accepted: July 17, 2013

Online Publication Date: August 22, 2013 